\title{
The Role of Nutrition in Fighting Free Radicals
}

\section{Cavalli TG and Santos $\mathrm{MG}^{*}$}

Department of Physical Education, Federal University of Paraná (UFPR), Parana, Brazil

*Corresponding author: Santos MG, Department of Physical Education, Federal University of Parana (UFPR), Parana, Brazil, Tel: (41) 9996 5822, E-mail: mariagisele@yahoo.com

Citation: Cavalli TG, Santos MG (2015) The Role of Nutrition in Fighting Free Radicals. J Nutr Health Sci 2(4): 405. doi: 10.15744/2393-9060.2.405

Received Date: July 16, 2015 Accepted Date: November 24, 2015 Published Date: November 25, 2015

\begin{abstract}
This paper aims to review in literature the main mechanisms of oxidative stress, pointing out the major formed metabolites, the mechanisms of cell damage and major antioxidants. Oxygen is essential to human life. The formation of free radicals (FR) is closely related to oxygen consumption, a mechanism that occurs with an incomplete reduction of this molecule. The oxidative stress, mechanism which is characterized by the imbalance between the FR formation and action of antioxidants in the body, can cause numerous cellular damage related to various injuries such as cancer, atherosclerosis, hypertension, emphysema, among other. The antioxidants are extremely important in fighting the damage in the body, which can be extrinsic or intrinsic sources.
\end{abstract}

Keywords: Free Radicals; Oxidative Stress; Antioxidants

\section{Introduction}

It is observed today a growing number of diseases related to the development of free radicals. So there is greater need for understanding the formation mechanisms and defense against free radicals, in order to understand the processes dependent on these species in the physiological mechanisms of physical exercise, and the pathophysiological mechanism of the diseases.

It was in the 1980s, which unveiled the first mysteries that related physical exercises and free radicals, which in this period aroused the curiosity of some researchers.

The consequences of physical exercises performed in exhausting situations can be very serious, reaching even to promote the carcinogenic mechanism.

Therefore it is seen the need for further clarification of these mechanisms, with a literature search, to understand the mechanisms of formation of free radicals, oxidative stress and antioxidants related to physical exercise.

\section{Free Radicals}

Oxygen is essential for cell life, but at the same time can cause tissue damage $[1,2]$.

The deleterious aspect is not provided of molecular oxygen, for this has low reactivity does not cause oxidative damage, but the intermediate products of its metabolism, free radicals (FR), are directly involved in oxidative processes and harmful to the cell [3]. Ghrorayeb, et al. (1999) defined oxidation as "result" of the exchange of electrons between atoms and molecules" [4].

Oliveira, et al. (2004) clarified that molecular oxygen does not react directly with the substrates [3]. When transported to the mitochondria, which has the fundamental role of receiving hydrogen ions and electrons (reduction process) extracted from the substrates (oxidized) by means of several enzymatic reactions when occurs the redox mechanism (oxidation and reduction), which appear in both cells, there is a transfer of energy (controlled) of the chemical bonds of substrates for adenosine triphosphate (ATP). Considering the chemical characteristics of the oxygen and the metabolic pathways of its use, there may be some reactions that cause harmful effects in their lives.

According to Andrade Júnior, et al. (2005), main oxygen metabolism pathway is that which has as a final result the reduction reaction, the water as the compound where there is the incorporation of four electrons at the end of the respiratory chain [5]. If there is a reduction of oxygen with a lower number of electrons, there is formation of free radicals of oxygen intermediates, or simply Free Radicals (FR).

According to Oliveira, et al. (2004) and Urso, et al. (2003), there is a supposition which between 2-5\% of the oxygen used by the mitochondria (cellular respiration process) could result in sequential univalent reduction and form reactive oxygen species $[3,6]$. 
Andrade Júnior, et al. (2005), Ghorayeb, et al. (1999) and Bianchi, et al. (1999), Ferreira, et al. (1997), Signorini, et al. (1995) determined that the electronically RF is an atom or molecule with one or more electrons (an odd number) is not matched in the last electric layer, independent existence [4,5,7-9]. This position, of unpaired electrons, makes the FR, extremely unstable, reactive and short half-life molecules, which according to Zoppi, et al. (2003) [10] undertake the intracellular DNA and Bacuri, et al. (2000) reported reducing electron compounds such as proteins and lipids, promoting consequently damage to biological systems [11].

The FR are produced in our body naturally, through oxidative metabolic processes that are often extremely useful, such as in cases that there is the need for activation of the immune system where the macrophages use the hydrogen peroxide to destroy bacteria and foreign bodies and also being beneficial in the detoxification of drugs. Nitric oxide has positive factors, when referring to the production of blood vessel relaxing factor (Schneider, et al. 2004) [12].

The FR may be produced by endogenous or exogenous sources [2].

To Porto, et al. (2001), the FR can be formed from the cleavage of a covalent bond between two atoms where each atom receives only one electron, or electron-transfer reactions [13]. Formed the FR, it may react with molecules, radicals and non-radical.

To Shami, et al. (2004), the FR are continuously produced during metabolic processes and act as mediators for the transfer of electrons in various biochemical reactions, developing relevant functions in metabolism [14].

Ramos, et al. (2000) emphasized that the FR formed primarily in the mitochondria, but through the action of enzymes and the oxidation of small molecules $\mathrm{O}_{2}$ in other tissues, its formation may occur out of mitochondria [15].

The most important free radicals derived from oxygen are:

- Superoxide Radical $\left(\mathrm{O}_{2}^{*}\right.$-)

Is formed from the reduction of $\mathrm{O}_{2}$ with one electron [5] during maximum activation of neutrophils, monocytes, macrophages and eosinophils, occurring in almost all aerobic cells. Shows little reactivity in aqueous medium [8].

- Hydrogen peroxide $\left(\mathrm{H}_{2} \mathrm{O}_{2}\right)$

Electronically is not considered an FR, for not having unpaired electrons in the electron orbit, but it is a metabolite of extremely harmful oxygen cells, as part of the reaction that produces the radical $\mathrm{OH}$, and due to its ability to high toxicity, especially in the presence of iron and copper, can cause other FR $[5,8]$.

- Hydroxyl Radical $\left(\mathrm{OH}^{*}\right)$

It is the most deleterious free radicals, according to Barreiros, et al. (2006), [16] due to its very short half-life and is very difficult to be sequestered in vivo. It is the reactive species, more reactive of the oxygen metabolism (mROS) in biological cells. In addition to the high reactivity, the hydroxyl radical may inactivate various proteins (enzymes and cell membrane) to oxidize the sulfhydryl group present in the protein disulfide bridges [8].

Formation reactions of Hydroxyl Radical, according to Andrade Júnior, et al. (2005) [5]:

1. Homologous fission of the $\mathrm{O}-\mathrm{O}$ bond of the molecule $\mathrm{H}_{2} \mathrm{O}_{2}$

2. $\mathrm{H}_{2} \mathrm{O}_{2}$ mix with iron salt (Fenton reaction)

$\mathrm{Fe}^{+2}+\mathrm{H}_{2} \mathrm{O}_{2}->\mathrm{Fe}^{+3}+{ }^{*} \mathrm{OH}+\mathrm{OH}^{-}$

The hydroxyl radical may also be formed when a reduced form of copper comes in contact with hydrogen peroxide, as reaction:

$\mathrm{Cu}^{+}+\mathrm{H}_{2} \mathrm{O}_{2}->\mathrm{Cu}^{+2}+{ }^{*} \mathrm{OH}+\mathrm{OH}^{-}$

3. Interaction of hydrogen peroxide with superoxide radical (Haber-Weiss reaction)

$\mathrm{O}_{2}^{-*}+\mathrm{H}_{2} \mathrm{O}_{2}->\mathrm{O}_{2}+\mathrm{H}_{2} \mathrm{O}+{ }^{*} \mathrm{OH}$

- Radical hidroperoxila $\left(\mathrm{HO}_{2}^{*}\right)$

Protonated form of superoxide radical (which has a hydrogen proton), and evidence claim to be a more reactive superoxide radical which, by its ability to initiate destruction of cell membranes more easily [8].

- Nitric oxide $\left(\mathrm{NO}^{*}\right)$

It is a gaseous, inorganic, colorless element, having an unpaired electron. Has modulator/messenger role in several essential biological processes and can be considered potentially toxic, in oxidative stress situations, with the generation of oxygen intermediates and antioxidant system deficiency. For Francisco Neto, et al. $(2005),[17,18]$ in addition to maintaining a persistent state of vasodilatation: nitric oxide in the presence of free radicals, specifically when combined with the hydroxyl radical, can become a powerful oxidant.

- Singlet Oxygen $\left(\mathrm{O}_{2}^{*}\right)$

According to Mafra, et al. (1999) [19] singlet oxygen is formed when the basic oxygen absorbs energy, making it an electronically excited species. 
More deleterious form of oxygen to the body, the cause or the middle of the photo-induced toxicity of $\mathrm{O}_{2}$ in living organisms. The half-life depends on the environment in which it finds, in aqueous medium, a time of very short half-life due to reaction with the $\mathrm{H}_{2} \mathrm{O}$ molecules, where the singlet oxygen returns to as triplet oxygen. In organic medium, the half-life is increased, which may cause some chemical reactions with certain electron acceptors for incorporation $\mathrm{O}_{2}$ [16].

These molecules exemplified above, are generated in clinical situations where hypoxic microenvironment are followed by microenvironments of re-oxygenation. Exemplifying some situations that run this mechanism: hemodynamic shock, sepsis, systemic inflammatory response, respiratory failure, among others [5].

Andrade Júnior, et al. (2005) [5] described the primary cellular damage caused by free radical reactions:

Proteins - the oxidation of amino acids by FR induces physical changes in the proteins they compose (fragmentation phenomenon, aggregation, and susceptibility to proteolytic digestion). When referring to fragmentation, the authors reported that proteins are selectively fragmented in proline residues (hydroxyl radical), also the amino acids histidine and arginine (those which are closely associated with transition metals). The hydroxyl radical provides the aggregation of proteins, due to its high ability to form crosslinks. Protein degradation is a result of changes in the conformation produced by the action of free radicals.

Carbohydrates - simple monosaccharides are rapidly autoxidation under physiological conditions to form as one of the reaction results hydrogen peroxide.

Lipids - the authors report the action of free radicals in lipids based on in vitro studies, where the peroxidation of polyunsaturated fatty acids usually involves three processes: initiation, propagation and termination. At initiation, formation takes place of a conjugated diene by subtracting a hydrogen atom by FR with good reactivity.

$\mathrm{H}+{ }^{*} \mathrm{OH}->{ }^{*}$ lipid $+\mathrm{H}_{2} \mathrm{O}$

The propagation of lipid peroxidation comes from the interaction of molecular oxygen with carbon, the result hydroperoxide radical, where it removes hydrogen atoms from other lipid molecules, forming lipid hydroperoxide.

${ }^{*}$ Lipid $+\mathrm{O}_{2}->{ }^{*}$ Lipid $-\mathrm{O}_{2}$ (hydroperoxide)

${ }^{*}$ Lipid $-\mathrm{O}_{2}+$ Lipid $-\mathrm{H}->^{*}$ Lipid + Lipid $-\mathrm{O}_{2} \mathrm{H}$ (lipid hydroperoxide)

With the presence of catalytic metals, according to the authors say, the decomposition of the hydroperoxide results in the formation of alkoxy and peroxyl, which can start a chain reaction, propagating lipid peroxidation, characterized as the largest source of cytotoxic products. They are mainly involved in lipid peroxidation, linoleic acid, arachidonic, docosahexaenoic acid and other polyunsaturated fatty acids.

\section{Free Radicals Sources}

The main sources of free radicals, according to Shami, et al. (2004) [14] are cytoplasmic organelles that metabolize oxygen, nitrogen and chlorine, causing a great amount of metabolites (Figure 1).

Porto, et al. (2001) [13] reported four endogenous sources such as responsible for the production of known FR:

1. Electrons originating from mitochondrial respiratory chain - involves complex NADH coenzyme Q reductase and other forms of reduced coenzyme Q (oxygen in cells is processed, with reaction from partially reduced oxygen molecules, with the formation of free radicals).

2. Escape of electrons originating from the cytochrome P450 and cytochrome b5 in the endoplasmic reticulum (can metabolize toxins that can react with oxygen, originate FR).

3. Phagocytic cells (due to chronic infections that increase FR production levels).

4. Peroxisomes (when degrade tissue or other lipid molecules, producing $\mathrm{H}_{2} \mathrm{O}_{2}$ as an intermediate).

The main exogenous sources to Porto, et al. (2001), [13] which may increase the production of free radicals, from the redoxcycling substances:

1. Paraquat (contact herbicide).

2. Diquat (herbicide).

3. Alloxan (substance with selective and destructive action on pancreatic b cells and induces diabetes, formation of superoxide and hydroxyl radicals, which characterizes the cytotoxicity of this compound (Lima, et al. 2001) [20].

4. Doxorubicin (produced chemical in cigarette burns and ionizing radiation).

Soares, et al. (2002) [21] also includes as generating exogenous sources of FR:

5. Air pollution,

6. Organic solvents,

7. anesthetics and

8. Pesticides. 


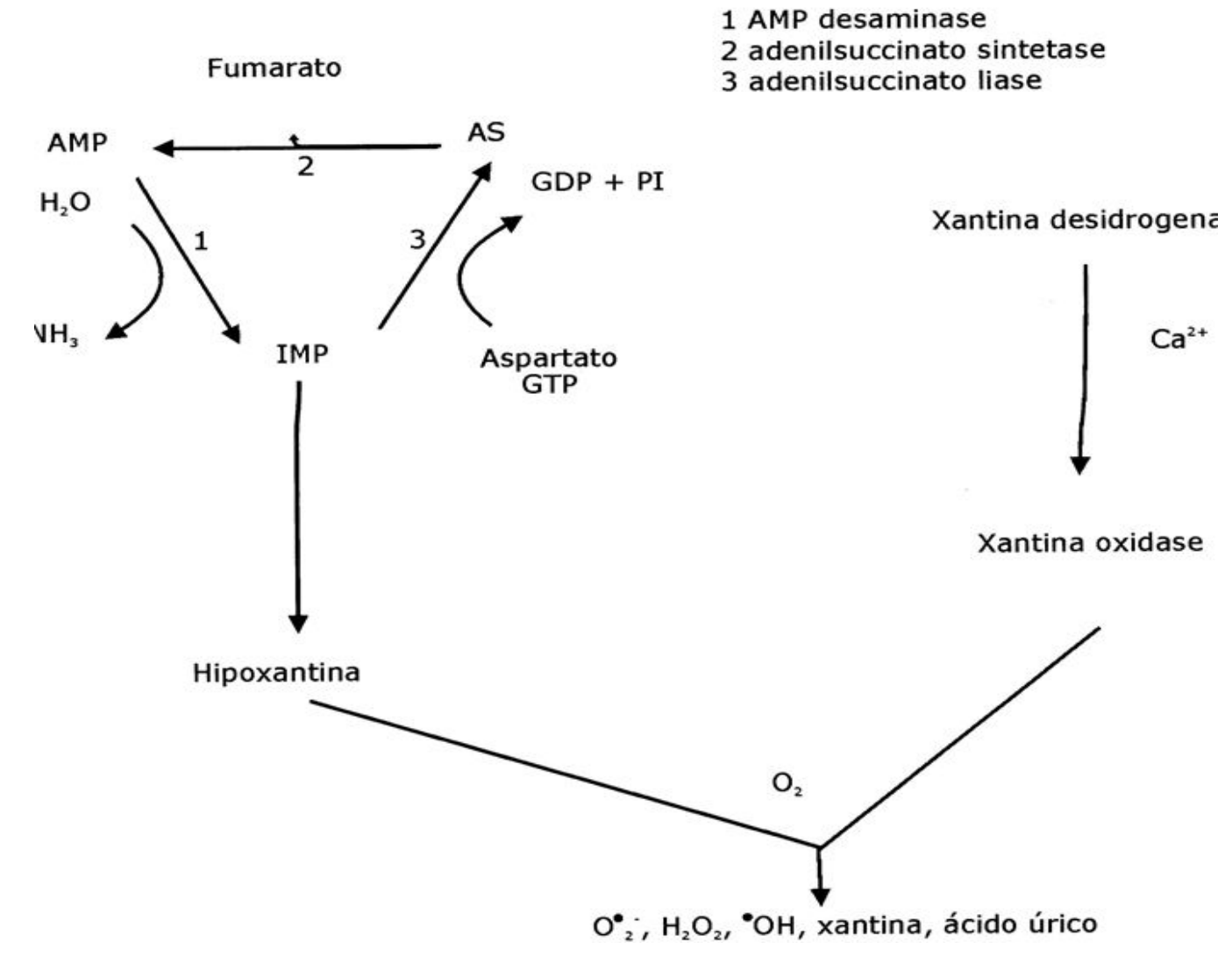

Source: adaptaed by Pereira S, et al. in Metabolismo Celular e Exercício Físico: Aspectos Bioquimicos e Nutricionais, 2004 [22] Figure 1: Mechanisms of Tissue Injury by Process of Cellular Ischemia and Reperfusion

\section{Free Radical Production in Exercise}

The muscular system can be considered as free energy transformation site in kinetic energy. When in skeletal muscle rest gets about $10-20 \%$ of blood, but when subjected to exercise, increases the volume to $85-90 \%$, with a consequent increase in the supply of glucose and oxygen (AGUILAR-Silva, et al. 2002) [23].

Despite the beneficial effects of physical activity are well known, is currently being reviewed in literature the potential for possible adverse and harmful effects, based on evidence that high aerobic metabolism during exercise increases the production of ROS in the body [24].

With exercise, according to Soares, et al. (2002) [21] there is a 10-20 times the volume of total consumed oxygen induction $\left(\mathrm{VO}_{2}\right)$ and an increase of 100 to 200 times the oxygen uptake by muscle tissue, where Silveira, et al. (2004) Zoppi, et al. (2003) reported that 2-5\% of the oxygen consumed originate from free radicals, this increase in oxygen induced by exercise is associated with such increased production of reactive species [1,10]. The induction of FR by exercise is classified as exogenous source of stimulus [2].

The generation of FR or ROS (reactive oxygen species) in physical exercise, seems to be associated to both the success and the failure of adaptive training mechanism. It was observed in mid-1990 that the ROS were able to produce biphasic effects on the contractile function of skeletal Muscle not fatigued. When at baseline, the ROS at low levels were essential for the production of normal strength of skeletal muscle [25].

Koury, et al. (2003) reported that during exercise occur several adaptive physiological mechanisms to compensate the effort made. Intense physical exercise increases energy metabolism and leads to excessive formation of ROS, which in turn can contribute to cause cell damage and impair athletic performance [26].

Ji, et al. (1999) reported that mitochondria would be the first place to generate free radicals during exercise. The mitochondrial lipid peroxidation is enhanced after exercise, accompanied by the loss of thiol protein and inactivation of oxidative enzymes [27].

Silveira, et al. (2004) said that when the reactive oxygen species are produced in low concentrations in muscle cells, cause positive physiological effects, such as increased $\mathrm{Ca}^{2+}$ permeability, thereby increasing contractility force and regulation of gene expression [1].

To Grorayeb, et al. (1999), the damage caused by oxidative stress to DNA caused by extreme exercise (exhausting), points to a risk of premature aging and cancer development [4]. 
According to Zoppi, et al. (2003) there is strong evidence that refer to the increased production of free radicals with the muscle fatigue installation process, thus installing the process of muscle injury [10].

Skeletal muscles continuously produce a cascade of intermediate metabolites, low molecular weight diffusible, monoeletronic from the reduction of oxygen, also called FR [25].

For Gandra, et al. in addition to superoxide, hydroxyl radical, hydrogen peroxide, skeletal muscle also produces nitric oxide radical $\left(\mathrm{NO}{ }^{*}\right)$, from the reaction catalyzed by the enzyme nitric oxide synthase from the amino acid arginine [25]. In turn, the $\mathrm{NO}^{\star}$ may react with $\mathrm{O}_{2}{ }^{*}$, the result being peroxynitrite (ONOO-), an unstable intermediate high reactivity. Pôrto, et al. (2001) emphasizes that peroxynitrite decomposes quickly in a large number of toxic substances $\left(\mathrm{NO}_{2}+, \mathrm{NO}_{2}\right.$ and $\left.\mathrm{OH}^{*}\right)$, a phenomenon that occurs under physiological conditions [13]. Pereira, et al. (2004) show that nitric oxide and derivatives significantly increase their concentration during exercise [22].

Silveira, et al. (2004) explained that nitric oxide from the muscle contraction in low concentration conditions, are seen as responsible for physiological phenomena such as metabolic regulation, blood flow regulation, gene expression and modulation in muscle contraction process, however, in high concentrations, significantly contribute to the reduction of strength and contractility, accelerated fatigue process and is a great contributor to muscle injuries, and potentially toxic, altering the intracellular redox balance, becoming oxidized [1].

Pereira, et al. (2004) reported that in the physical exercise occurs tissue ischemia mechanism, which is when occurs $100 \%$ utilization of the maximum muscle contraction, occurring tissue ischemia, these remain temporarily in anoxia, resulting in an intensification of lactic and alactic anaerobic metabolism and consequently increasing the production of ammonia and ATP degradation products [22]. With muscle relaxation, the $\mathrm{O}_{2}$ returns to flow normally, promoting the formation of oxy-radicals and hydrogen peroxide, favoring the occurrence of cell damage, where Francisco Neto, et al. (2005) report such an occurrence emphasizing the pathophysiological mechanism of the involvement of free radicals in ischemia-reperfusion syndrome are causing cell damage [18].

According to Soares, et al. (2002) high intensity sports activities can activate three main ways of formation of free radicals, which are mitochondrial production, cytoplasmic production and production favored by iron and copper ions [21]. However the manner that obtains energy through aerobic metabolism are more ease to promote the release of reactive oxygen species, with athletes these modalities linked to aerobic exercise, major consequences of the presence of FR.

The extent of cell damage from free radicals during exercise, according to Ji, et al. (2000) [28] is not determined only by the amount of free radicals formed but also by the body's antioxidant capacity. Aguilar-Silva, et al. (2002) [22], reported that regular exercise can lead to regulation of antioxidant enzyme activity in skeletal muscle.

According to Oliveira, et al. (2004) aerobic exercise training can help and benefit the tissue tolerance to oxidative stress [3]. Aerobic exercise can promote increase in enzymatic antioxidant defenses and non-enzymatic, and promotes a lower production of reactive oxygen species by mitochondria during sub-maximal exercise in the same relative intensity $\left(\% \mathrm{VO}_{2} \mathrm{max}\right)$.

\section{Oxidative Stress}

Bianchi, et al. (1999) stated that the formation of free radicals in vivo come from the catalytic action of enzymes during the electron transfer process occurring in cellular metabolism [7].

The existence of an imbalance between the rate of production of reactive oxygen species and the removal rate thereof by the antioxidant system, in biological organisms, is characterized as a temporary redox imbalance. The persisting imbalance, more intensely, is characterized as chronic oxidative stress [3].

The definition of oxidative stress, according to Prada, et al. (2004), Montano, et al. (2003) and Bianchi, et al. (1999) when there is an imbalance between oxidants and antioxidants molecules, resulting in cell injury caused by free radicals [7,29,30].

For Souza Júnior, et al. (2004), oxidative stress involves an increase in the formation of superoxide anion, hydrogen peroxide and hydroxyl radical, among others, due to damage to the antioxidant defenses [22].

Bianchi, et al. emphasized that when there is occurrence of oxidative stress in an amount greater than the antioxidant defenses, free radicals involved in the reaction, can cause cell damage and death [7].

Prada, et al. (2004) emphasized that physical exercise is a condition that influences the balance between attack of oxidants and antioxidant defenses of the body [29].

For Oliveira, et al. (2004), the increased production of reactive oxygen species, exceeding the capacity of antioxidant defense, resulting in oxidative stress, occurs mainly in untrained individuals [3].

Physical activity of high intensity can increase the intracellular formation of free radicals and consequently promote oxidative stress (Souza Junior, et al. 2004), where Aguilar-Silva, et al. (2002) emphasized that the mechanism of ischemia/reperfusion, or oxidation of catecholamines, are considered processes that may cause such stress in intense physical exercise [22,23]. 
As tissue protective mechanism against the action of free radicals produced during exercise, according to Prada, et al. (2004), the antioxidant enzymes such as superoxide dismutase, catalase, glutathione reductase and glutathione peroxidase, seem to respond to the stimulus in an adaptive manner, increasing their activities in the tissues and organs of trained individuals, occurring mainly this adaptively in endurance type training [29].

\section{Oxidative injury}

Free radicals promote reactions with biological substrates, may cause damage to the biomolecules and consequently cause problems for human health [16].

Souza Junior, et al. (2004), said that the increase in metabolic activity encourages the development of oxidative lesions in biomolecules [22].

Pereira Souza Junior, et al. (2004) [22] emphasized that when FR are produced in sufficient quantity to activate the defense mechanisms against oxidative stress, can occur together and consequently metabolic disorders and cellular including DNA strand breaking (often an early effect), increase in $\mathrm{Ca}^{2+}$ free intracellular ionic transport mechanism membrane or other specific proteins injury, oxidation of cysteine residues, cytoplasmic protein and lipid peroxidation and, according to Zoppi, et al. (2003) ultimately, alters and impairs intracellular metabolism and can consequently cause cell death [10].

The intensive attack, specifically the hydroxyl radical, according to Barreiros, et al. (2006) can result in mutations in DNA, which consequently can lead to development of cancer in humans within 15 to 20 years [16].

In the DNA, the radical attacks the nitrogenous bases as deoxyribose. The most severe damage is caused to those DNA and RNA. When the DNA chain is broken, it can be reconnected in another location, changing the order of their bases, a phenomenon that characterizes one of the basic processes of mutation and accumulation of damaged bases that may trigger oncogenesis. An enzyme that has its modified amino acids may lose their activities, or even take on different activities [16].

The same authors reported that the amino acids and proteins, the radical attacks primarily cysteine, histidine, tryptophan, methionine, phenylalanine, and to a lesser extent, attacks the arginine and asparagine. These attacks can cause damage to amino acids as cleavages connections with or without generating fragments and crosslinks, which may have as a consequence the loss of enzyme activity, difficulties in active transport across cell membranes, citose and cell death.

According to Souza Junior, et al. (2004) due to training, sporting events, events that promote a high increase in cellular metabolic activity, injuries from oxidative stress can take on huge dimensions [22].

Shami, et al. (2004) and Bianchi, et al. (1999) [7,14] reported some etiologies of diseases related to cellular damage from the action of free radicals: Bianchi, et al. (1999) cited some diseases like heart disease, atherosclerosis, arthritis, diabetes, cataracts, multiple sclerosis, chronic inflammation, cerebral dysfunction, emphysema, aging and diseases of the immune system [7].

\section{Antioxidants}

Sies, et al. (1995) Antioxidant defined as "any substance present in low concentrations as compared to the oxidized substrate, delays or inhibits the oxidation of these substrates effectively" [31].

The antioxidants protect biological systems against the damaging effects of reactive oxygen species against different targets [19].

In summary Bianchi, et al. [7] said that antioxidants are agents responsible for inhibition of the damage caused by free radicals in cells, and, according to Oliveira, et al. (2004), an antioxidant ceases to be oxidized to form a radical least reactive and easier recycling [3].

Soares, et al. (2002) stated that the oxidative mechanisms can be prevented through changes in environmental conditions and the use of antioxidants with the property to prevent/decrease the triggering of oxidative reactions [21].

Antioxidants are able to inhibit the oxidative action of various substrates in simple molecules to complex polymers and biosystems, the mechanism involving the FR formation inhibition which allow the initiation step, and the mechanism covers the elimination of FR important in stage of propagation, such as alkoxyl and peroxyl, by donating hydrogen electrons to these molecules, interrupting the chain reaction [21].

Bianchi, et al. (1999) emphasized that the occurrence of a mild oxidative stress, usually is accompanied by an increased production of enzymatic antioxidant defenses. The antioxidants may be classified as enzymatic and non-enzymatic [7].

\section{Protection mechanisms}

To protect against oxidative action promoted by free radicals, the body has chemical and enzymatic defense mechanisms [32].

For Bianchi, et al. (1999), [7] antioxidants involved in the area of protecting the body in the following ways:

- Prevent the formation of FR in the first instance, especially inhibiting the chain reactions with iron and copper.

- Intercept the FR generated in cellular metabolism or from exogenous source, preventing the action on lipids, protein, amino acid, the formation of double bonds of the polyunsaturated fatty acids and on the basis of DNA, preventing damage and loss of integrity (Table 1). 


\begin{tabular}{|l|l|}
\hline Non enzymatic & Enzymatic \\
\hline Vitamin E (Alpha-Tocopherol) & Superoxide Dismutase \\
\hline Beta-Carotene (Precursor Of Vitamin A) & Catalase \\
\hline Ascorbic Acid (Vitamin C) & $\begin{array}{l}\text { NADPH Quinone } \\
\text { Oxidoreductase }\end{array}$ \\
\hline Flavonoids & Glutathione Peroxidase \\
\hline Plasma Proteins & Repair Enzymes \\
\hline Selenium & \\
\hline Glutathione & \\
\hline Chlorophyllin & \\
\hline L-Cysteine & \\
\hline Curcumin & \\
\hline
\end{tabular}

Source: Bianchi, et al. Radicais livres e os principais antioxidantes da dieta, 1999 [7]

Table 1: Main Defense Antioxidant Agents

Ferreira, et al. (1997) reported that the antioxidant processes mentioned above are related to intracellular antioxidant defense, reduced glutathione (GSH), superoxide dismutase (SOD), catalase, glutathione peroxidase (GSH-Px), and vitamin and as structural antioxidant defense membrane [8].

- Removal Process/repair of the DNA molecule of the damages and restoring the damaged cell membranes [7].

In repair mechanism according to Ferreira, et al. (1997), the sources of antioxidants are the ascorbic acid (vitamin C), glutathione reductase (GSH-Rd) and also GSH-Px among others [8].

In certain situations there could be an adaptive mechanism in response to generation of free radicals with an increased synthesis of antioxidant enzymes [7].

According to Bianchi, et al. (1999) the in vivo antioxidant efficiency depends: FR types formed, where the radicals are generated, analysis and methods for identifying the damages, and the optimal dose for the protective mechanism [7].

Finally, Pereira B, et al. (1996) emphasized that the balance of chemical and enzymatic antioxidant defenses, derives an optimal maintenance of the cells [32] (Figure 2).

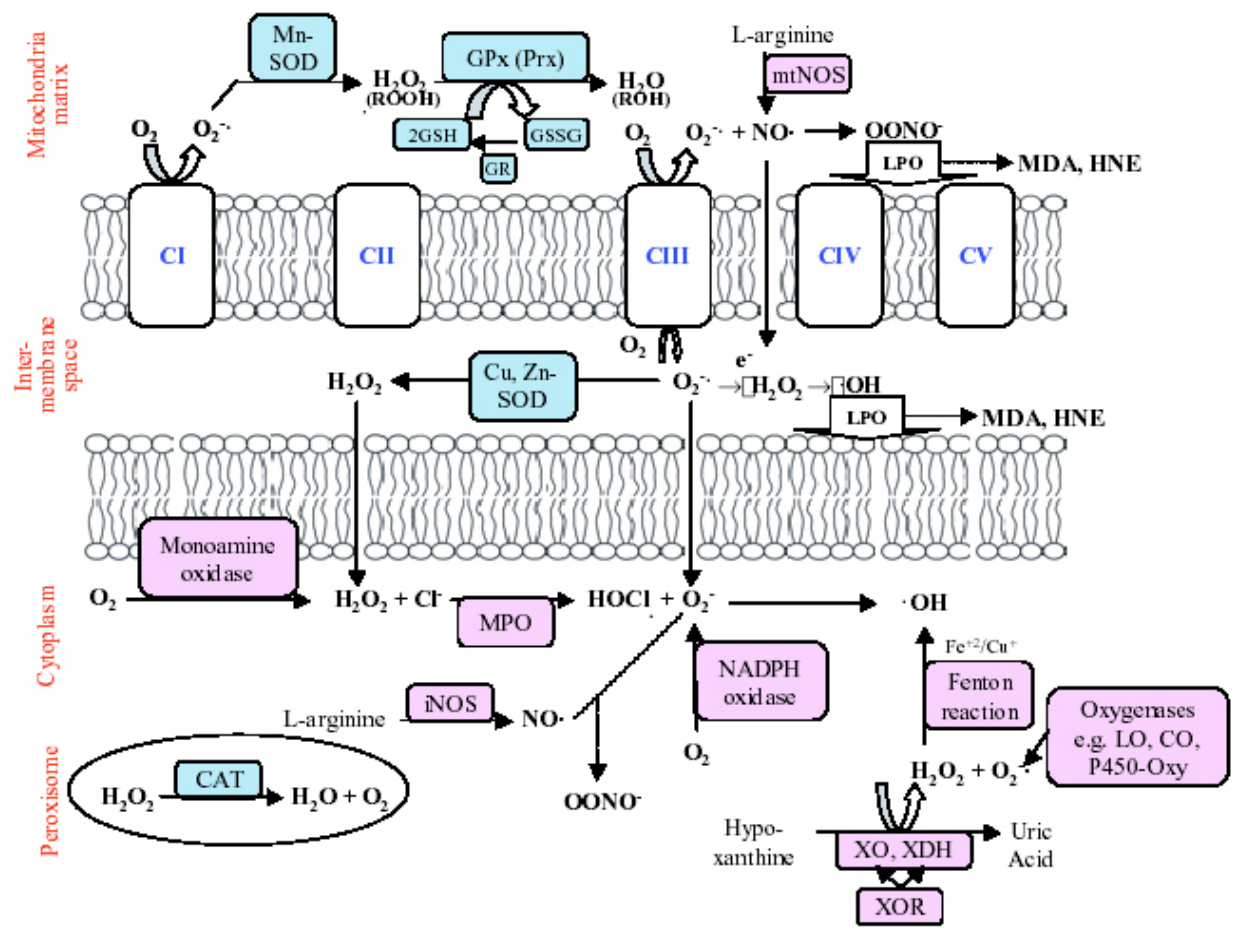

Source: Zacks, et al. An overview of chagasic cardiomyopathy: pathogenic importance of oxidative stress, 2005 [33]

Abbreviations: CAT (catalase); CI, CII, CIII, CIV, CV (respiratory chain complex I, II, III, IV, V); CO (cyclooxygenase); CuZnSOD (copper zinc superoxide dismutase); GSH (glutathione); GPx (glutathione peroxidase); GR (glutathione reductase); GST (glutathione S transferase); GSSG (glutathione disulfide); HNE (4 nonenal hydroxyl); iNOS (induced nitric oxide synthesis); LO (lipoxygenase); MDA (malondialdehyde); MnSOD (superoxide dismutase magnesi um); mtNOS (mitochondrial nitric oxide synthesis); NO (nitric oxide); MPO (myeloperoxidase); Oxy-P-450 (P450-dependent oxygenations); XO (xanthine oxidase); XDH (xanthine dehydrogenase); XOR (xanthine oxidoreductase); LPO (lipid peroxidation); PRX; ROOH (alkyl hydroxides)

Legend: pink boxes: formation mechanism of EROS/blue boxes: enzymes and non-enzyme antioxidant

Figure 2: Enzymatic and Non-Enzymatic Protection 


\section{Enzymatic protection}

Zacks, et al. (2005) stated that the main antioxidant enzymes are catalase (CAT), superoxide dismutase (SOD), peroxiredoxin (PRX) and glutathione peroxidase (GSH-Px) [33].

Insulin deficiency modifies the action of antioxidant enzymes SOD, catalase and GSH-Px as much as the content of lipoperoxides, indicated in diabetic animal tissues [32].

Barreiros, et al. (2006) [16] explained the enzymatic reactions better known as antioxidants:

1. Reaction composed of two types of SOD (superoxide dismutase), which catalyze the destruction of superoxide anion radical, converting it into oxygen and hydrogen peroxide. Naturally occurring superoxide anion radical decomposition process ${ }^{\star} \mathrm{O}_{2}$, but with the greatest need for concentration of superoxide anion radical. The presence of SOD favors this disproportionation, even at low concentrations of superoxide, allowing the removal of $\mathrm{O}_{2}$. The first form of SOD enzyme existing in the body, is composed of $\mathrm{Cu}^{+2}$ and $\mathrm{Zn}^{+2}$ as redox center, the reaction taking place in the cytosol where its activity is not affected by oxidative stress. The second form of SOD enzyme, which possesses $\mathrm{Mn}^{+2}$ as redox center, occurring in mitochondria, and its activity is increased in the presence of oxidative stress.

2. Formed by catalase (CAT), which converts the hydrogen peroxide $\left(\mathrm{H}_{2} \mathrm{O}_{2}\right)$ into $\mathrm{H}_{2} \mathrm{O}$ and $\mathrm{O}_{2}$, by disproportionation.

$$
2 \mathrm{H}_{2} \mathrm{O}_{2} \underset{\mathrm{NADPH}}{\stackrel{\text { catalase }}{\longrightarrow}} \mathrm{O}_{2}+2
$$

3. Reaction consisting of reduced glutathione (GSH) in conjunction with glutathione peroxidase (GSH-Px) and glutathione reductase (GSH-Rd). The presence of selenium in the enzyme (selenocysteine) explains the importance of this metal in antioxidant activity in living beings. This system also catalyzes the dismutation of hydrogen peroxide to water and oxygen, and glutathione operates in cycles between their GSH and GSH-Px-Rd shape. Glutathione reduces hydrogen peroxide to water in the presence of glutathione peroxidase, with formation of a disulfide bridge, then being regenerated next.

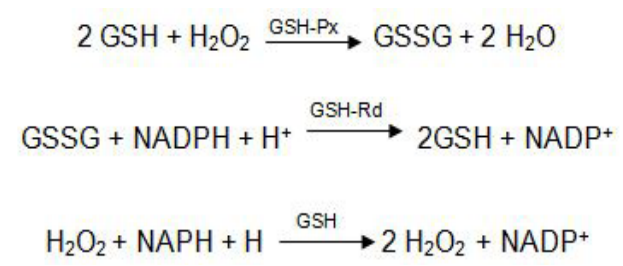

\section{Non-Enzymatic Protection}

Angelis, et al. (2001) suggested on the basis of epidemiological evidence that people increase the intake of fruits and vegetables as a preventive way to reduce risk of degenerative diseases [34].

The use of antioxidant substances, from the diet or from synthetic compounds, is one of the defense mechanisms against free radicals. Diets rich in fruits and vegetables are associated with decreased risk of developing diseases associated with the accumulation of free radicals. The vitamins $\mathrm{A}, \mathrm{C}$ and $\mathrm{E}$, flavonoids and carotenoids obtained through the diet, are important in intercepting FR [7].

According to Gey (1998) the beneficial effects of the interaction of vitamins C and E reveal effective inhibition of the peroxidation of lipids of cell protection [35].

\section{Phenolic Compounds}

One of the substances that compose the group of phenolic compounds is the phenol-acid, which is characterized by conferring antioxidant properties both in food and in organisms being used in the treatment and prevention of diseases. This substance is found in plants in free form or bound to sugars and protein [21].

Soares, et al. (2002), Barreiros, et al. (2006) reported that phenolic antioxidants act as radical captors, and occasionally as metal chelators, acting both in the initiation stage and propagation of the oxidative process [16,21]. They are found in soybeans, defatted soybean flour and isolated soy protein concentrate [21].

\section{Carotenoids}

The chemical structure of the carotenoids is composed of conjugated double bonds, which are responsible for its color and for its biological functions. They are responsible for sequester singlet oxygen (free radical) and remove the radical peroxides (FR) [14].

Recently, according to Barreiros, et al. (2006), and the function to disable the singlet oxygen, carotenoids can sequester the peroxyl radicals [16].

Shami, et al. (2004) [14] stated that carotenoids like beta-carotene, lycopene, zeaxanthin and lutein, exercise the functions of antioxidants in the lipid phase, blocking the free radicals that cause lesions on the lipoprotein membranes. 
According to Shami, et al. (2004), lycopene currently appears as one of the most potent antioxidants, mainly in the prevention of carcinogenesis and atherogenesis for protecting molecules such as lipids, low density lipoproteins (LDL), proteins and DNA [14]. The main sources, according to Shami, et al. (2004), are found in carrots and pumpkins (alpha and beta - carotene), tomatoes and derivatives (lycopene) and spinach (lutein) [14]. Shami, et al. defined carotenoids as natural colorants present in fruits and vegetables, such as carrots, tomatoes, spinach, oranges, and peaches among others [14].

\section{Ascorbic Acid}

Considered as plasma antioxidant, according to Zacks, et al. (2005) [33]. Vitamin C in accordance to Barreiros, et al. (2006), [16] is found in our body in the form of ascorbate. It is located in the aqueous compartments of tissues due to its high solubility. Ascorbate acts as a reducing agent, reducing transition metals $\left(\mathrm{Fe}^{+3}\right.$ and $\left.\mathrm{Cu}^{+2}\right)$ present in active sites of enzymes or in free form in the body. Can be oxidized by free radical, can be a good reducing agent, which arrives or is in tissue in aqueous medium and in the reaction with free radicals, form a radical (semi- dehydroascorbatase), which is little reactive. The ascorbate acts as an antioxidant due to convert of free radicals in radical species, rather reactive and harmless, can act against lipid peroxidation plays a major role in preventing cardiovascular disease and in conjunction with the alpha-tocopherol, acting in cell membranes.

The same authors report that ascorbate also has pro-oxidant properties, following the principles of Fenton reaction, where the Fe ${ }^{+2}$ ions and $\mathrm{Cu}^{+1}$ react with hydrogen peroxide to form hydroxyl radical, a process which the ascorbate, indirectly induces free radical reactions. However, the antioxidant properties are more evident than pro-oxidants, where iron ions are mostly linked to carrier proteins or storage in normal situations.

\section{Vitamin E}

Consists of four tocopherols, four tocotrienols, being the most active alpha-tocopherol. It acts as an important antioxidant in the inhibition of lipid peroxidation, and its efficiency, in the presence of ascorbate (cell membranes) and ubiquinone (mitochondrial membrane) [16].

Alpha-tocopherol is active in cell membranes, where reduces ROS and lipid peroxidation from the radical attack (Zacks, et al. 2005). For Ji, et al. (2000), deficiency of this vitamin alone or deficiency associated with exercise, causes a significant increase in the production of free radicals and thus an increase in cellular disorders such as lipid peroxidation, loss of sarcoplasmic reticulum and mitochondrial uncoupling [28,33]. It also states that this vitamin is essential for normal functioning of cells during exercise.

\section{Coenzyme $Q_{10}$}

It is a fat-soluble ubiquinone, being the only endogenously synthesized lipid presenting redox function. It is the largest constituent of the mitochondrial membrane, Golgi apparatus and membrane of lysosomes. Ubiquinone ingested as a food supplement is distributed mainly in liver and blood plasma is not absorbed by the membranes with a high concentration of this element. Biosynthesis is very active up to 30 years in humans, period of stagnation of its production takes place, and after this age, ubiquinone levels decrease [16].

The ubiquinone supplementation has shown positive effects, according to Barreiros, David, et al. (2006), in the treatment of heart disease, muscle degeneration and other degenerative diseases [16]. The main role of ubiquinone in the mitochondrial inner membrane occurs in an essential process for the production of ATP. It has antioxidant power as sequesters free radicals, among them, disabling the superoxide anion and singlet oxygen.

\section{Uric acid}

In the mid-1980s, unveiled the effective role of uric acid in combating free radicals, able to protect the DNA and lipids from the harmful action of these species. It is found in most tissues as urate anion. By having a high polarity, its action is limited to the aqueous medium. In individuals with atherosclerosis, the concentration of uric acid in the blood may be high, which indicates a compensatory mechanism of the body to control oxidative stress [16].

Barreiros, et al. (2006) point out as its most effective action, to react against the peroxyl radicals in aqueous medium, preventing their entry into the membrane, preventing damages to be caused, thereby promoting antioxidant protective effect of DNA and lipids [16]. The radical anion urate, may be regenerated to urate by ascorbate, being urate able to recover structures already attacked and damaged by free radicals.

\section{The Role of Nutrition in Fighting Free Radicals}

Based on the macronutrient intake recommendations, the carbohydrates that compose the Western diet used as an energy source are divided as follows: approximately $60 \%$ in the form of polysaccharides, $30 \%$ as sucrose and $10 \%$ as lactose [36].

Recommendations for Americans and Canadians second UNITED STATES OF AMERICA - DRI (2005) is presented in the following proportion: carbohydrates $45-65 \%$ of the daily intake, protein $10-35 \%$ and fat 20-35\%. For Brazilians, according BRASIL, RDC 360 of December 23, 2003 of the National Health Surveillance Agency, it is estimated a balanced intake of macronutrients and micronutrients for adults in 2000 kilocalories per day, and that carbohydrates account for $60 \%$ of this amount, proteins and lipids 15\% 25\%, respectively, as shown in the Table 2 below:

According to Mahan, et al. (2002), a diet vegetable-based, such as fruits, vegetables, grains and legumes, associated with moderate consumption of poultry and fish and other meat, provide support for the maintenance of organs by helping the body to defend itself against diseases [37] (Figure 3). 


\begin{tabular}{|l|l|}
\hline Energetic Value & $2000 \mathrm{kcal}-8400 \mathrm{~kJ}$ \\
\hline Carbohydrates & 300 grams \\
\hline Protein & 75 grams \\
\hline Total Fat & 55 grams \\
\hline Saturated Fat & 22 grams \\
\hline Dietary Fiber & 25 grams \\
\hline Sodium & 2400 milligrams \\
\hline
\end{tabular}

Source: BRASIL, RDC 360 of 23/12/03

Table 2: Nutrient reference values for Brazilians

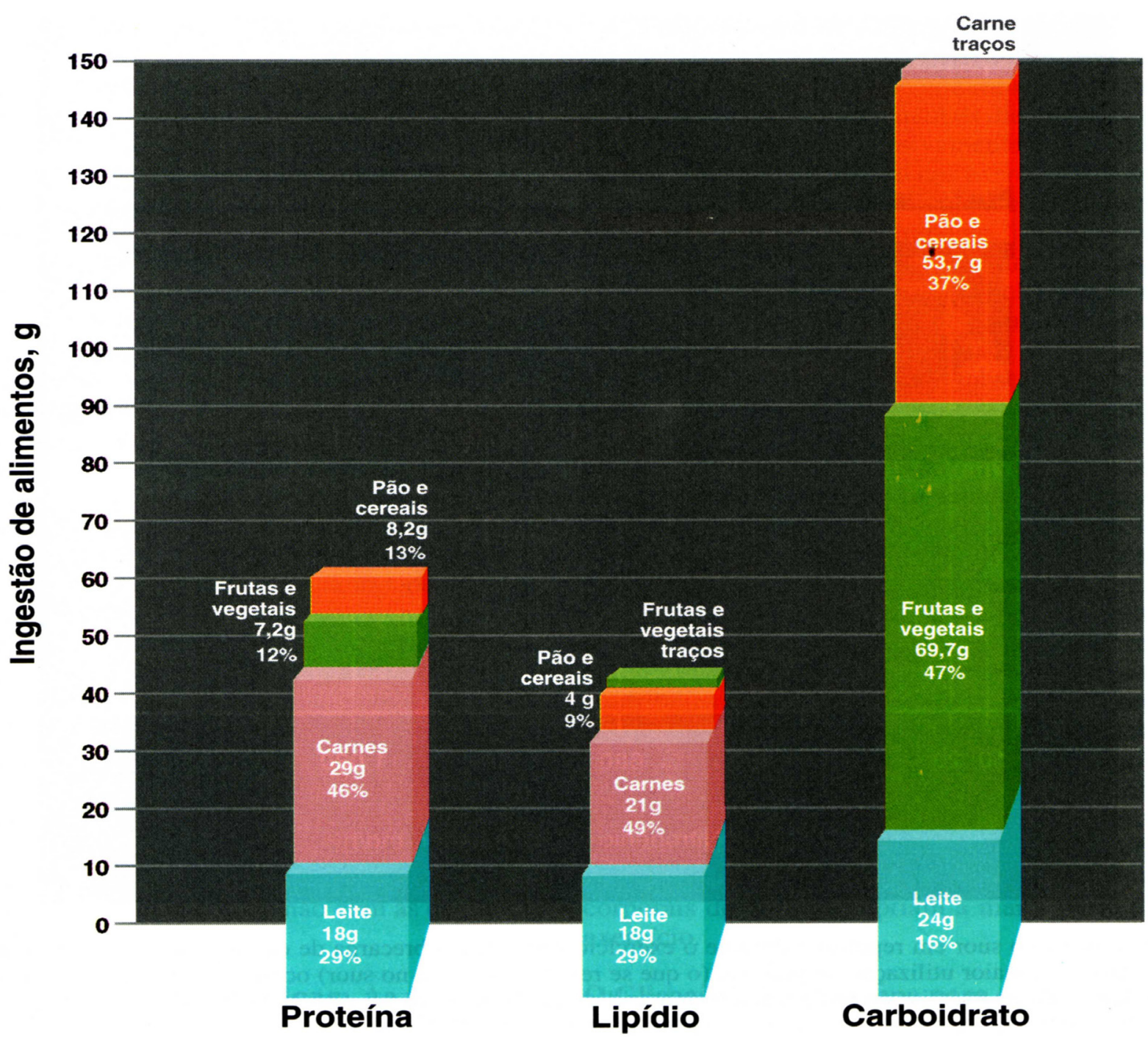

Source: Mcardle, et al. Nutricao para o desporto e exercício, 2001 [38]

Figure 3: Dietary recommendations for physically active people

The foods of vegetables-based not only have protein, fat, carbohydrates, fiber, minerals and vitamins, have a large number of nonnutrient compounds, called phytochemicals naturally occurring in this food grade [37].

McArdle, et al. (2001) [38] state that the herbal substances which are found in plants, such as isocyanate, are powerful stimulants of natural detoxifying enzymes in the body, found in broccoli, cabbage, cauliflower, kale, and other cruciferous vegetables and that according to Waitzberg, et al. (2004) [36] are important compounds in preventing cancer. So some plant components can act against different stages of the carcinogenic process, as in prevention throughout the period of initiation and promotion, and changing neoplastic cellular processes that lead to cancer progression.

The protection of antioxidant vitamins may be related to numerous other nutrients and substances the chemical composition of fruits, cereals and vegetables which act protecting against diseases like cancer, heart disease, hypertension, diabetes, osteoporosis, premature aging and cataracts [38]. 


\section{Conclusion}

An adequate diet as a source of extrinsic antioxidants, combined with a training of adequate intensity can favor in minimizing oxidative processes in the body and prevent the onset of diseases.

\section{References}

1. Silveira LR (2004) Considerações críticas e metodológicas na determinação de espécies reativas de oxigênio e nitrogênio em células musculares durante contrações. Arq Bras Endocrinol Metab 48: 812-22.

2. Ricardo Russo BS, Keihan Rodrigues MV (1990) Radicais livres, exercício e envelhecimento. Revista Brasileira de Ciências e Movimento 4: 61-85.

3. Oliveira EM, Ramires PR, Lancha Junior AH (2004) Nutrição e Bioquímica do Exercício. Rev Pauli Ed Fís 18: 7-19.

4. Ghorayeb N, Barros Neto TLO (1999) Exercício: Preparação Fisiológica, Avaliação Médica, Aspectos Especiais e Preventivos. Sao Paulo: Editora Atheneu.

5. Andrade Junior DR, de Souza RB, dos Santos SA, de Andrade DR (2005) Os radicais livres de oxigênio e as doenças pulmonares. J bras Pneumol 31: 60-8.

6. Urso ML, Clarkson PM (2003) Oxidative Stress, exercise and antioxidant supplementation. Toxixology. 189: 41-54.

7. Pires Bianchi MDL, Greggi Antunes LM (1999) Radicais livres e os principais antioxidantes da dieta. Rev Nutr 12: 123-30.

8. Ferreira ALA, Matsubara LS (1997) Radicais livres: conceitos, doenças relacionadas, sistema de defesa e estresse oxidativo. Rev Assoc Med Bras 43: 61-8.

9. Signorini JL, Signorini SL (1995) Atividade física e radicais livres: aspectos biológicos, químicos, fisiopatológicos e preventivos. São Paulo: Editora Î́cone.

10. Zoppi CC, Antunes-Neto J, Oliveira Catanho F, Fernando Goulart L, Motta E Moura, et al. (2003) Alterações em biomarcadores de estresse oxidativo, defesa antioxidante e lesao muscular em jogadores de futebol durante uma temporada competitiva. Ver. Paul Educ Fís São Paulo 17: 119-30.

11. Bacuri RF (2000) Nutrição e suplementação esportiva. São Paulo: Phorte Editora.

12. Schneider CD, de Oliveira AR (2004) Radicais livres de oxigênio e exercício: mecanismos de formação e adaptação ao treinamento físico. Rev Bras Med Esporte 10: 308-13.

13. Porto WG (2001) Radicais Livres e Neurodegeneraçao. Entendimento Fisiologico: Base para Nova Terapia? Ver. Neurociências. Sao Paulo 9: 70-6.

14. Esh Shami NJI, Machado Moreira EA (2004) Licopeno como agente antioxidante. Rev Nutr 17: 227-36.

15. Ramos G, Alves A, Hermes-Lima M (2000) Radicais livres, antioxidantes e a adaptabilidade animal. Ln: NINO EL-HANI C, VIDEIRA AA. P. O que e vida. Para entender a biologia do século XXI. Rio de Janeiro: Relume Dumara.

16. Barreiros Andre LBS, Juceni PD (2006) Estresse oxidativo: relação entre geração de espécies reativas e defesa do organismo. Quím. Nova 29: 113-23.

17. Sant'Ana DLM, Vieira LM, Carvalho MDG (2003) Revisao sobre oxido nitrico. J Bras Patol Med Lab 39: 343-50.

18. Neto AF, Baptista Silva JCC, Fagundes DJ, Percário S, Novo NF, et al. (2005) Estudo das alterações oxidativas, da capacidade antioxidante total e do óxido nítrico, em ratos submetidos à isquemia e reperfusão de membros posteriores. Acta Cir Bras 20: 134-9.

19. Mafra D, Abdalla DSP, Cozzolino SMF (1999) Peroxidação lipídica em pacientes com insuficiência renal crônica. Rev Nutr 12: 205-12.

20. de Lima Ma, de Lima LMB, Rita DPC, Navarro FC, Tatsukawa RS, et al. (2001) Analise Quantitativa das células das ilhotas pancreáticas em ratos sob efeito de aloxana. Medicina Ribeirao Preto 34: 308-14.

21. Eduardo SS (2002) Ácidos fenólicos como antioxidantes. Rev Nutr 15: 71-81.

22. Pereira B, Souza Junior TP (2004) Metabolismo Celular e Exercício Físico: Aspectos Bioquímicos e Nutricionais. Editora Phorte, Sao Paulo.

23. Silva RH, Cintra BB, Milani S, Moraes TP, Tsuji H (2002) Estado antioxidante do sangue como indicador da eficiência do treinamento em nadadores. Rev Bras Cien e Mov Brasilia 10: 7-11.

24. Mcardle WD, Katch FI, Katch VL (1998) Fisiologia do exercício: energia, nutrição e desempenho humano. 4a ed. Editora Guanabara Koogan.

25. Gandra PG, Alves AA, Macedo DV, Kubota LT (2004) Determinacao eletroquímica da capacidade antioxidante para avaliacao do exercício físico. Quím Nova 27: $980-5$.

26. Koury JC, Donangelo CM (2003) Zinco, estresse oxidativo e atividade física. Rev Nutr 16: 433-41.

27. Ji LL, Leeuwenburgh C, Leichtweis S, Gore M, Fiebig R, et al. (1999) Oxidative stress and aging. role of exercise and íts influences on antioxidant systems. Ann N Y Acad Sci 854: 102-17.

28. JI LL (2000) Antioxidants and Oxidatite Stress in Exercise. Society for Experimental Biology and Medicine, 222: 283-91.

29. Prada FJA, Voltarell FA, de Oliveira CAM, Gobatto CA, Macedo DV, et al. (2004) Condicionamento aeróbio e estresse oxidativo em ratos treinados por natação em intensidade equivalente ao limiar anaeróbio. Revista Brasileira Ciências e Movimento. Brasília 12: 29-34.

30. Montano MAE, Soares DG, Salvador M (2003) Avaliacao do estresse oxidativo e contaminação de chumbo em praticantes de tiro esportivo. Maringa Acta Scientiarum Heath Sciences 25: 63-7.

31. Sies H, Stahl W (1995) Vitamins E and C, B-carotene, and other carotenoids as antioxidants. Am J Clin Nutr, Bethesda 62: 1315-21.

32. Pereira B (1996) Radicais livres de oxigênio e sua importancia para a funcionalidade imunológica. Motriz 2: 2.

33. Zacks MA, Wen JJ, Vyatkina G, Bhatia V, Garg N (2005) An overview of chagasic cardiomyopathy: pathogenic importance of oxidative stress. An Acad Bras Cienc 77: 695-715.

34. Carlota AR (2001) Novos conceitos em nutricao: reflexoes a respeito do elo dieta e saúde. Arq Gastroenterol out./dez 38: 269-71.

35. Gey KF (1998) Vitamins E plus C and interacting co-nutrients required for optimal health. Biofactors, Oxford 7: 113-74.

36. Santos MG, González de Suso JM, Moreno A, Cabanas M, Arus C (2004) Muscular energetic metabolism study in athletes by 31P-MRS. Rev Assoc Med Bras 50: $127-32$.

37. Mcardle WD, Katch FI, Katch VL (2002) Fundamento da fisiologia do exercício. 2a ed. Editora Guanabara Koogan.

38. Mcardle WD, Katch FI, Katch VL (2001) Nutricao para o desporto e exercício. Editora Guanabara Koogan. 


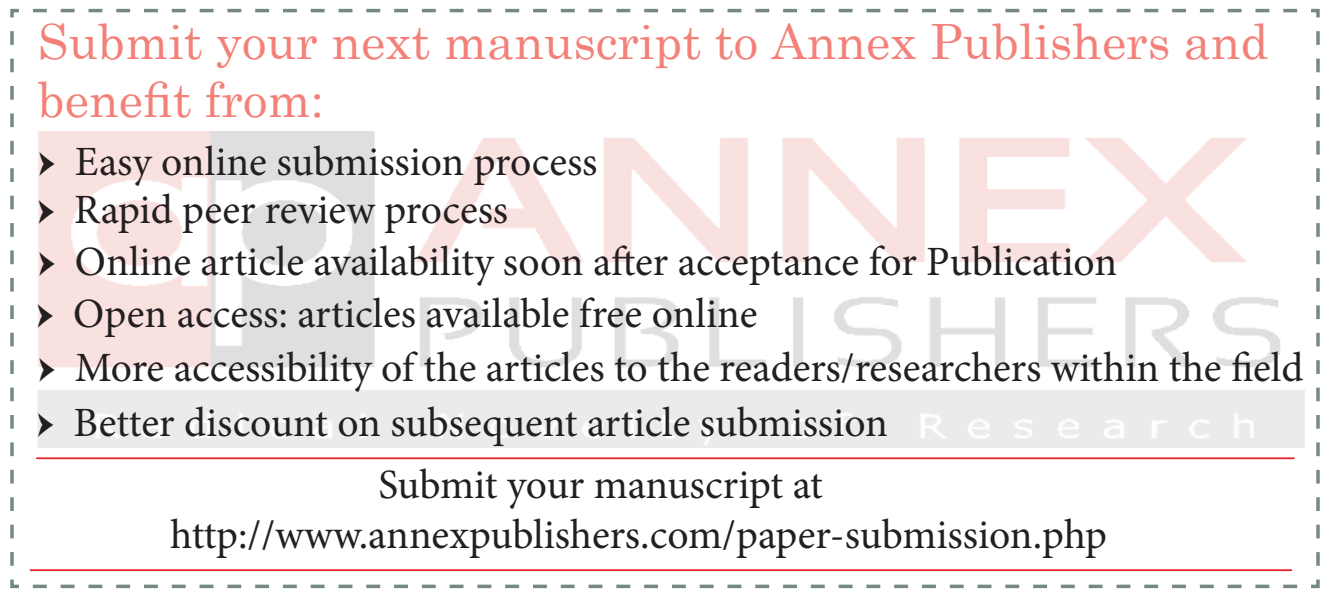

